\title{
THE BASIC TENETS OF INTESTATE (CUSTOMARY) SUCCESSION LAW IN ANCIENT EGYPT
}

\author{
NJ van Blerk*
}

\section{ABSTRACT}

This article discusses the basic tenets of customary intestate succession law in ancient Egypt as one "branch" of succession law. It considers the initial role of religion in the emergence of succession law as background. It furthermore discusses the basic structure or order of inheritance from a legal perspective. An attempt is made to indicate that there was a structure followed which changed very little over time although the emphasis and connection with religion diminished. The position of descendants, ascendants, husband and wife and their legal relationship to the deceased is discussed against the backdrop of the nuclear family and the estate being treated as a res incorporalis. Consideration is given to elements of parentela and per stirps possibly present. The position of the eldest son as sole heir and "caretaker" is discussed. Ultimately the focus is on what we can learn about customary-intestate succession law in ancient Egypt from early texts in the Old Kingdom through to the New Kingdom.

Keywords: Ancient Egypt; customary intestate succession law; belief in the afterlife; sustenance; custom; tradition; precedent; nuclear family; eldest son

* LLB MA D Litt \& Phil (Unisa). Lecturer in Ancient Near Eastern Studies in the Department of Biblical and Ancient Studies at the University of South Africa. 


\section{Introduction}

This article is part of a bigger endeavour into the study of "testamentary disposition documents" in ancient Egypt. ${ }^{1}$ In order to understand the different documents the ancient Egyptians used as testamentary dispositions, it is necessary to have a clear understanding of the ancient Egyptians' customary intestate succession law. This article aims at explaining the basic tenets of ancient Egyptian customary intestate succession law.

Succession law in ancient Egypt emerged from the belief in the afterlife. Belief in the afterlife necessitated that the deceased be sustained after death. It was the responsibility, within the family context, of the eldest son and the children (and family) to fulfil this duty. The nuclear family and the protection of the family property as a "whole" were essential in this regard. Elements of intestate and testate succession law are identifiable as the deceased could also make arrangements prior to death by way of a testamentary disposition. One can obviously not suggest that the ancient Egyptians had testate and intestate succession law as we understand it today, but elements of testate and succession law are present. This article focuses on one branch of succession law, namely the basic tenets of "intestate succession law" elements in ancient Egypt. This is also historically the oldest.

The term "customary intestate succession" is used for purposes of this article. This notion represented the ancient Egyptians' customary way of dealing with intestate matters which were effectively the result of the obligation and duty for sustenance resting with the immediate nuclear family. It would furthermore support the ancient Egyptians' respect for tradition, custom and precedent. One may argue that this is an indication of an early development of jurisprudence within customaryintestate succession law.

Generally, when someone dies intestate, it means that he or she died without a valid will. This also appears to have been the case in ancient Egypt even though the Egyptians did not have a specific document used as a "will". The ancient Egyptians used a variety of documents which served the purpose of a "testamentary disposition" with the intention of altering the "customary-intestate succession law".

The law of intestate succession is important in determining who the beneficiaries of the deceased are and this was also the case in ancient Egypt. The "customaryintestate succession" law is applicable unless a "testamentary disposition" was made prior to death.

1 The testamentary disposition made prior to death in ancient Egypt is similar to the Roman law "testament" (see Seidl 1957: 57). As Seidl (1957: 58) correctly emphasises: "Wenn man überhaupt den Ausdruck 'Testament' verwenden will, um damit eine ägyptische Urkunde zu bezeichnen, so muß man sich wieder darüber klar sein, daß man damit Vorstellungen, die aus dem römischen Recht stammen, dem Leser suggeriert." It is for this reason that the term "testamentary disposition" is rather used in this study. 
An extraordinary characteristic of ancient Egypt was the fact that women had greater freedom of choice and more equality under social and civil law than their contemporaries in Mesopotamia or even the women of the later Greek and Roman civilisations. $^{2}$ Women could, furthermore, inter alia inherit property, including immovable property, and both men and women could inherit equally and from each parent separately. ${ }^{3}$

Our main sources for "customary-intestate succession law" in ancient Egypt are quite late and date mostly, but not only, from the Demotic Codex Hermopolis from the Late Period. ${ }^{4}$ The law of succession is, however, not always the most progressive or dynamic part of a civilisation's legal system, which means that we are actually able to form a proper understanding of a civilisation's idea of succession law. This is especially true in the case of ancient Egypt which was more conservative and followed tradition, custom and precedent.

The Codex Hermopolis contains portions of a variety of texts from different periods which have most probably been reworked by a jurist of the early third century BCE. ${ }^{5}$ A number of legal matters are covered in the Codex Hermopolis, and the final texts of this Code deal with the law of succession and more specifically with the position of the "eldest son" in disputed cases. ${ }^{6}$ It furthermore addresses various actions regarding inheritance. The Codex Hermopolis, however, is not the only source and other sources include documents relating to testamentary dispositions, adoptions and disputes. ${ }^{7}$ These sources will now be discussed.

\section{What does succession law entail?}

The law of succession is basically concerned with the transfer of property, as vested in a person at his death, to another person or persons. This presupposes the existence of the notion of private property (property owned by a person). When a person dies, his assets pass by inheritance to people qualified to succeed the deceased. The rules of the law of succession determine who the qualified person or persons are and it also establishes the scope of the benefits.

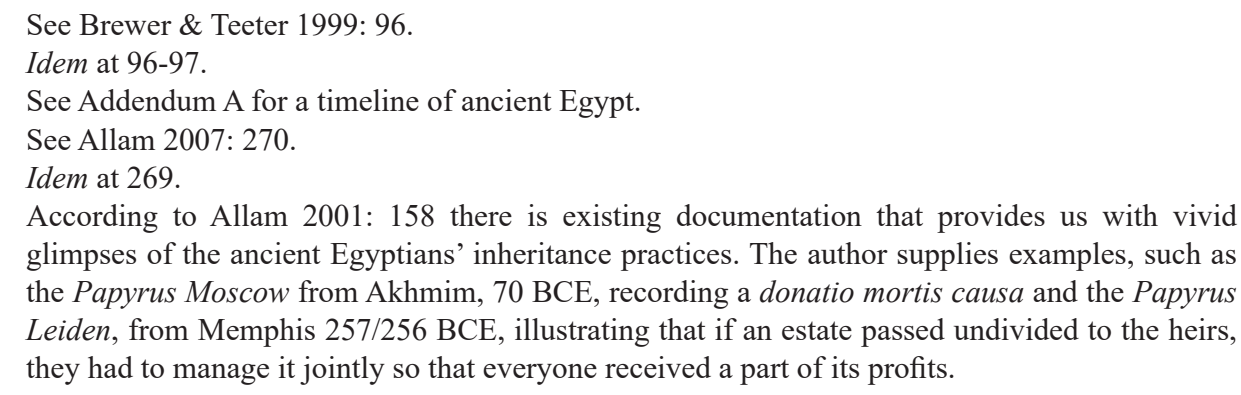
glimpses of the ancient Egyptians' inheritance practices. The author supplies examples, such as the Papyrus Moscow from Akhmim, 70 BCE, recording a donatio mortis causa and the Papyrus Leiden, from Memphis 257/256 BCE, illustrating that if an estate passed undivided to the heirs, they had to manage it jointly so that everyone received a part of its profits. 
It is important to remember that the law of succession should always be studied within its broader social context. The law of succession, besides being a product of society, may also perform a function for the society. Friedman (quoted in Fleming and referring to succession ${ }^{8}$ ) observes that the law and rules -

\begin{abstract}
help define, maintain and strengthen the social and economic structure. They act as a kind of pattern or template through which the society reproduces itself each generation. Rules of inheritance and succession are, in a way, the genetic code of a society. They guarantee that the next generation will, more or less, have the same structure as the one that preceded it. In the long run, for example, there could be no upper class or aristocracy without rules about the inheritance of wealth and privilege, which permit the upper class or aristocracy to continue. And if rules permit free transfer of property and freedom of testation, a middle class society can be created and maintained.
\end{abstract}

According to Fleming - in a very general sense - all rules of law (which include all rules of succession) serve identifiable social functions. ${ }^{9}$ To describe social behaviour it is important to analyse the motivation behind actions, and not simply the actions themselves as listed in the text. ${ }^{10}$ Although such an analysis might often seem subjective, it could well be the only way to put an isolated legal text into its wider context. ${ }^{11}$ It is therefore important to understand the ancient Egyptians world and the wider influences of their motivations, influenced by among others religion, family and economic factors when considering texts.

\title{
3 The importance of belief in the afterlife
}

Belief in the afterlife was an all-encompassing belief in ancient Egypt. The hope for eternal life influenced every aspect of their lives. For the ancient Egyptians the living and the dead formed part of the same community, resulting in a moral relationship between the dead and the living. ${ }^{12}$ After death, the deceased would be sustained not only by prayers and inscriptions on the tomb walls and on funerary papyri, but also by an active mortuary cult. ${ }^{13}$ Special arrangements were made in order to ensure that the upkeep and provisioning of the tomb continued in perpetuity, and a special priest, the $k a$-priest, was appointed and undertook this duty in return for an income from the deceased's estate. ${ }^{14}$ This duty was very often that of the eldest son. For the wealthy this responsibility lay with the priests and family, while the poor relied exclusively on family members for their offerings. ${ }^{15}$ This duty on the family fell on the nuclear family.

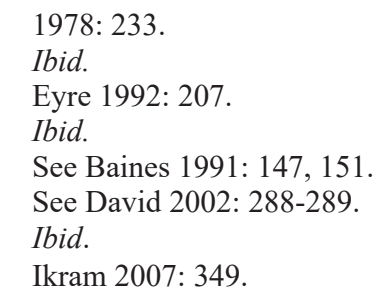


Examining, for instance, the tombs of Giza or Saqqara (Old Kingdom), one immediately gets the impression that a prominent motif in the decorations is the bringing of offerings for the deceased. ${ }^{16}$ The Egyptians were always concerned with sustenance in the afterlife, since they aspired to have a life much like their earth-like existence after death. ${ }^{17}$ They resorted to magic and rituals in the hope of securing sustenance for themselves in the afterlife and depended upon the actual delivery of food and drink at their tombs and in front of their statues. ${ }^{18}$ This reaffirms the notion of the living and the dead being part of the same community in the ancient Egyptians' mind.

The deceased was dependent upon the actual delivery of food and drink by his or her family..$^{19}$ It was practice in ancient Egypt that the next generation would take responsibility for the care of the deceased and would receive the deceased's property. ${ }^{20}$ There was consequently a strong sense of obligation by the descendants and the nuclear family was essentially responsible for this duty.

There was a link in the private sphere between the mortuary cult and the inheritance of property since inheritance was conditional upon the son's fulfilment of his cult duties towards the deceased estate. ${ }^{21}$ The task of the eldest son and the priests was consequently to keep the $k a$ of the deceased supplied, who would, in return for fulfilling his duty, receive a share of the largest endowment. ${ }^{22}$ Since the mortuary cult was intended to last in perpetuity it was hoped that the land set aside for the endowment would remain in the family from generation to generation. ${ }^{23}$

The first signs of succession law are firmly rooted in the religious environment. It would be the ancient Egyptians "obsession" with the afterlife that necessitated sustenance after death. This obligation on the family and family property would introduce a custom within the family which would be followed as a precedent in their culture. According to David, because of the emphasis placed on funerary customs, many legal transactions are concerned with situations relating to funerary property. ${ }^{24}$

\section{The nuclear family as a social unit}

The social function of succession law refers specifically to maintaining and protecting the family as a social unit, which explains why the law of succession

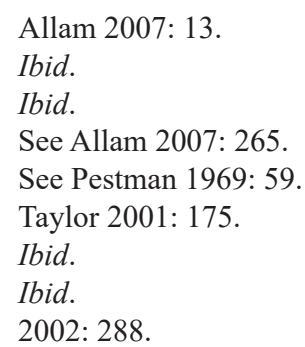


is also influenced by the social trends affecting the family. ${ }^{25}$ The basic Egyptian family unit consisted of a man, a woman and children they may have. ${ }^{26}$ Adoption was possible in ancient Egypt which meant that adopted children formed part of the nuclear family as is evident inter alia from the Papyrus Ashmolean Museum 1945.96 (Adoption Papyrus) from the New Kingdom (Twentieth Dynasty). Intestate succession law, for example, prescribes that the immediate family members are the beneficiaries of the de cuius' estate. ${ }^{27}$

For this reason it is important to understand the socio-economic life and norms in ancient Egypt, which should be taken into account when studying the first signs of the development of succession law in ancient Egypt. The social context of ancient Egypt was extremely important considering the fact that the idea was for the immediate family, specifically the children, to inherit in order to sustain the deceased, and also to keep the family property together. In practical terms someone had to take responsibility at the death of the de cuius for certain matters pertaining to the burial process, as well as for matters pertaining to the deceased's property, of which the distribution of the inheritance was an important part.

The nuclear family was the core of Egyptian society: even the Egyptian gods were arranged into the same family groupings and many genealogical lists indicate how important family ties were. ${ }^{28}$ From "The Contendings of Horus and Seth" we know that values, such as justice ${ }^{29}$ and family solidarity, were very dear to the Egyptians. ${ }^{30}$ The earliest examples of inscriptions, texts and paintings reflect the importance of family in ancient Egypt and specifically the nuclear family.

\section{Family property}

The nuclear family in ancient Egypt was an essential part and foundation of their social life together, with the emphasis on protecting the family property. The very

25 Egyptian kinship terms lacked specific words to identify blood relatives beyond the nuclear family: see Brewer \& Teeter 1999: 95. Although these terms would sometimes be combined to express exact relationships (son's son etc), the simple terms commonly have an extended meaning covering several different biological and marital relationships (see Rowlandson \& Takahashi 2009: 110).

26 See Pinch 2000: 370-371

27 The de cuius refers to the deceased person. My definition of de cuius is a deceased person who has assets and thus an estate that needs to be dealt with after death. Hiemstra \& Gonin (2013: 405) translate de cuius as "erflater" in Afrikaans and as "testator" in English. In my opinion the Afrikaans translation is correct and it agrees with my own definition given above, while the English translation is incorrect, since "testator" only refers to a case where there is a will. It would prima facie appear that English does not have an unambiguous word for the de cuius.

28 See Brewer \& Teeter 1999: 95

29 Justice was central to the Egyptian world and a key element of Egyptian law.

30 Sweeney 2002: 143. 
earliest pious foundations emphasise the "protection of property as a unit". This played an important role in the way they viewed their initial obligation for sustenance of the deceased and the resulting emergence of succession law.

In ancient Egypt there was a formal system of private law under which property could be the subject of private transactions. ${ }^{31}$ This is supported by Goedicke since already in the Old Kingdom private people could own property and we can therefore postulate a legal sphere that may be summarised under the modern term "private law". ${ }^{32}$ According to Goedicke "law" and "property" are intimately connected, so that the existence of rights by private individuals presupposes the existence of private property.

Belief in the afterlife made it almost essential for particularly immovable property to stay intact within the family in order to sustain the deceased after his or her death. The institutio heredis was therefore a concept or idea not foreign to the ancient Egyptians, even though the concept might have been developed and defined by Roman law much later in history.

In Roman law the deceased's estate was regarded as an entity, a res incorporalis which passed to the deceased's heir, and this estate, viewed as universitas (a "whole"), was known as hereditas. ${ }^{33}$ This appears also to have been the case in ancient Egypt. Texts from earlier periods do not give us such informative details although these earlier texts disclose that a community of heirs existed in one form or the other, perhaps to prevent the fragmentation of the estate, ${ }^{34}$ and Pestman asserts that in the beginning the estate remained undivided and that this may have remained so for generations to come. ${ }^{35}$

It is important to note that immovable property was usually not divided among heirs, but held jointly by the family. ${ }^{36}$ From the Codex Hermopolis we have an example of property to be held jointly (and not divided) in column IX 19-IX 21 from which it is clear that the house itself is not divided, but was held jointly, with the profit to be divided (by the eldest son) among the co-owners if the house was sold. ${ }^{37}$

It would appear that the initial reason to keep the property intact was to make it economically functional for the duty of sustenance of the deceased, but that it was later done purely for economic reasons as piety (for sustenance) diminished.

This concept of the institution of a single heir appear to be present in ancient Egypt with the important role played by the eldest son to prevent the split-up of

31 David 2002: 288.

32 See Goedicke 1970: 190.

33 See Burdick 1989: 548.

34 See Allam 2001: 159.

35 See Pestman 1969: 64.

36 See Brewer \& Teeter 1999: 97.

37 Mattha 1975: 41. 
property into uneconomic plots, but also to fulfil the important role of taking charge of the required sustenance of the deceased (as will also be discussed infra). ${ }^{38}$

According to Versteeg, immovable property in ancient Egypt usually passed undivided in inheritance as it made practical sense to allow houses and agricultural fields to remain intact. ${ }^{39}$ The estate was therefore treated as an entity.

\section{What happens when the de cuius dies?}

According to Pestman, everything needs to be organised: the deceased must be mummified and buried, bills and burial tax must be paid and, if necessary, provision must be made for the widow and any minor children, etc. ${ }^{40}$ It is possible that the deceased him- or herself would have arranged these payments. But what happened if the de cuius did not make arrangements prior to death by means of a testamentary disposition? In order to answer this question it is necessary to ascertain what actually happened with the inheritance itself.

A cornerstone of Egyptian morality was the respect for one's parents, with the most fundamental duty of the eldest son (or occasionally daughter) being to care for his parents in their last days and to ensure that they receive a proper burial. ${ }^{41}$ The eldest son would take possession of the family property in order to prevent the property to be split up and in order for it to function as an economic unit so that it can provide the necessary sustenance for the deceased.

\section{The role of the "eldest son"}

It would appear, prima facie, that the eldest son's role in ancient Egypt was very similar to that of an executor or administrator. Of particular importance in ancient Egypt was the initial importance of and duty to sustain the deceased. This duty of managing the estate fell on the "eldest son" ${ }^{42}$ The word for "eldest son" is $\mathrm{SraA} .{ }^{43}$

38 Muhs (2016: 5) is of the opinion that the ancient Egyptian state was primarily interested in protecting and enforcing its own property rights for tax collection purposes. Thus the responsibility for protecting and enforcing individual property rights was often shared with a variety of formal and informal organisations, or even private social control. Muhs furthermore states that this is most evident in the early first millennium BCE, when the Egyptian state fragmented and the temples took over the responsibility for enforcing property transfer agreements.

39 2002: 139-140.

40 Pestman 1969: 64.

41 Brewer \& Teeter 1999: 95.

42 The eldest son often also inherited his father's job and position (see Brewer \& Teeter 1999: 97). The word for "eldest son" is SraA (see Allam 2001: 158).

43 See Allam 2001: 158 
The Codex Hermopolis (column VIII 30-31) states as follows:44 "If a man dies, he having lands, gardens, temple-shares (?) and slaves ... it is his eldest son who takes possession of his property (or better estate)."

Allam makes a valid observation that we might miss the point in a given succession if we always translate SraA by "eldest son", since passages in the Codex Hermopolis as well as provisions in marriage contracts indicate that the firstborn was not necessarily the favourite, but the SraA did come from ranks of the descendants. ${ }^{45}$ The Codex Hermopolis also gives an example of a case where the estate went to a son other than the SraA, and other similar situations are also mentioned in the law book.

Unless otherwise indicated, the undivided property was managed by the eldest son on behalf of all the heirs. ${ }^{46}$ The eldest son held the position, as it were, as head of the family and was also responsible for matters to be dealt with when someone died. According to Allam the eldest son played a very important role in the succession and he could be any of the sons, or even a daughter in the absence of sons. ${ }^{47} \mathrm{~A}$ daughter could become "eldest son" if there were no male children (column IX 14-IX 16 of the Codex Hermopolis). ${ }^{48}$ The eldest son received more benefits and his or her share usually exceeded those of other heirs.

The Codex Hermopolis mentions that another child could take over the funerary obligations if the eldest son was unable or unwilling to do so, in which case this substitute "eldest son" became entitled to the additional inheritance which had been earmarked for the biological eldest son. ${ }^{49}$ This substitute eldest son then administered his father's estate and became a guardian for his mother, brothers and sisters. If the deceased had no children it was possible for the deceased's brother to become "eldest son" who was preferably the firstborn male child of the deceased..$^{50}$ If there was no male child, the rule was that a closer degree of kinship was more important than gender, which in turn was more important than order of birth. ${ }^{51}$ It would therefore

44 According to Strudwig (2005: 57) the following text conventions are generally used in the translation of Egyptian texts:

[ ] enclose translations of restored text. Text in these brackets, in italics, is specifically speculative; ( ) enclose words that are not in the original text, but are added to clarify the translation. Text within these parentheses, in italics, serve the purpose to explain;

... indicate gaps in the text or words which cannot be translated;

$<>$ enclose words or parts of words which are omitted in the original text;

(?) follows words or phrases of which the translation is doubtful.

See, also, Mattha 1975: 39.

45 See Allam 2001: 158.

46 The children may in some cases act all together, as they have a definite right to inherit. In some cases the mother acts for the children, probably because they are still minors. See Pestman 1969: 65.

47 Allam 2001: 158.

48 See Mattha 1975: 40.

49 Versteeg 2002: 139.

50 See Lippert 2013: 3.

51 Ibid. 
appear that the word might preferably refer to the person acting as "caretaker" or "executor", acting in that capacity, rather than the biological eldest son.

Although we have good evidence for the hierarchy of the "eldest son" from the Codex Hermopolis, which is very late in Egyptian history, it was merely a compilation of earlier established law. Given the ancient Egyptians' tendency for custom, tradition and precedent it is most likely that very little changed over the years. Importantly we have much earlier confirmation of the role of the "eldest son". From the Old Kingdom (Fourth Dynasty) we have, for example, the Inscription of Heti, where the eldest son is specifically important since he must supervise the mortuary priests performing the rites for the deceased Heti. ${ }^{52}$ The assets as well as the other children are also placed under the eldest son's care who acts as an "administrator", a modern-day "executor" in Heti's case. Theodorides gives the following translation: ${ }^{53}$

As for all my children, truly, that which I have constituted for them, as assets of which they shall enjoy the usufruct, I have not granted any of them the right to dispose of his (share), as a gift or in consideration of payment (?) ... an exception being made for the son he may have and to whom he shall transfer (it). They are to act under my eldest son's authority as they would act with regard to their own property; for I have appointed an heir against the day - the latest possible - when I shall go to the West.

In the Inscription of Niankhka (Fifth Dynasty), Niankhka put all the members of his family association under the guardianship of his eldest son. Here the importance of the "eldest son" playing the role of administrator is once again highlighted.

The terminology of "eldest son" for the "caretaker" or "executor" could change or be expanded. The estate was later under the control of an administrator or trustee $(r w D)$ who could be one of the heirs. ${ }^{54}$ The undivided property is managed by an appointed administrator who administers the estate on behalf of all the heirs, and who in some texts from the New Kingdom is referred to as "representative" ( $r w d$

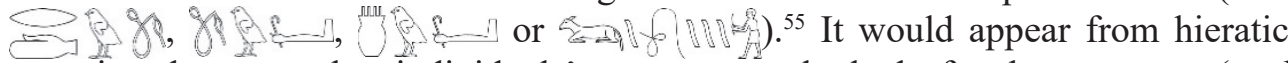
papyri and ostraca that individuals' estates were looked after by a trustee ( $r w d$ SP De one of the heirs. ${ }^{56}$ Pestman is of the view that although a woman could be appointed administrator, the eldest son was usually the obvious person to act as administrator in cases where no other arrangement was made. ${ }^{57}$

We find an example in the fourteenth century BCE where - in the scribe Mose's tomb inscription at Saqqara - mention is made of a woman, Urnero, who was

52 Jasnow 2003: 124.

53 1971: 293 .

54 See Allam 2001: 159.

55 Pestman 1969: 64. Besides the passage from the Inscription of Mes ( $14^{\text {th }}$ century), see also Papyrus Berlin 3047.8 (13 ${ }^{\text {th }}$ century). See, too, Helck 1963: 65-73.

56 See Shaw \& Nicolson 2008: 158.

57 See 1969: 64-65. 
appointed by an official from the supreme council to assume the responsibility of an administrator or trustee $(r w d)$ on behalf of her five brothers and sisters. ${ }^{58}$

The task of the administrator or trustee was not easy and there are numerous examples of litigation initiated by the heirs opposing the administrator or trustee. ${ }^{59}$ In the dispute mentioned by the scribe Mose, an official from the supreme council was called upon to carry out the division of the estate among the heirs. According to Allam a series of Demotic texts exists on which a lawsuit was based, and with a record of the proceedings during the trial. ${ }^{60} \mathrm{He}$ is of the opinion that this record, found in Papyrus British Museum 10591 (recto), is the most elaborate record of judicial proceedings from the ancient world.

Papyrus Berlin 9010 from the Old Kingdom is important for two reasons as it refers to a dispute by the eldest son (Tjau), and it also confirms the existence of customary-intestate succession. ${ }^{61}$ The eldest son disputes the existence of a "testamentary disposition" 62 made by his father and maintains the property should remain with him (implying the existence of customary-intestate succession). We read as follows from the papyrus: ${ }^{63}$ "But this Tjau has replied that his father never made it (this document) in any place whatever", and "But if he (Sobekhotep) does not produce the witnesses (irw) in whose presence this utterance was voiced, none of the said User's property shall be kept in his possession; it shall be kept in the possession of his son (ie the eldest son of User), the royal noble, the overseer of caravans, Tjau."

From the Middle Kingdom, Papyrus UC 32055 (Papyrus Kahun II 1) is an example about legal action taken by the eldest son, indicating the role of the eldest son as administrator similar to our present day executor. It indicates that the eldest son as administrator stepped into the shoes of the deceased in order to effectively enforce the completion of an outstanding legal action on behalf of the deceased and on behalf of the deceased's estate; acting therefore legally as executor on behalf of the estate in a matter of an "incomplete transactio" to recover the owing obligation. It also appear from Papyrus Ashmolean Museum 1945.97 ("Will" of Naunakht) that the eldest son might have been "compensated" for his administrative role as "caretaker" or "executor" as Naunakht awards a copper bowl as legacy to the eldest son in her testamentary disposition.

58 Allam 2001: 159.

59 Ibid.

60 Ibid.

61 The eldest son initially relied on the customary intestate succession law and disputed a testamentary disposition made prior to death (see Seidl 1957: 57).

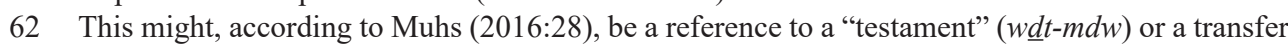
(imyt-pr) document serving as a testamentary disposition.

63 Trl by Theodorides 1971: 295-296. 


\section{Who are the intestate customary heirs?}

Looking at the practical order of inheritance in cases of "customary-intestate succession law" in ancient Egypt, it would appear that the inheritance would as a rule always first go to descendants before ascendants and that husband and wife did not inherit from each other. This may be explained in more detail:

\section{Husband and wife}

According to Baines it appears that marriage, being the prevalent state of Egyptian life, fell outside the religious context and that the institution of marriage existed with concomitant sanctions against adultery, but without evidence that any rituals or other religious observances were celebrated. ${ }^{64}$ Marriage seems to have been a social arrangement in order to regulate property rights. ${ }^{65}$ There is no evidence of any form of legal or religious ceremony in order to establish the marriage: ${ }^{66}$ it was a private affair in ancient Egypt in which the state took no interest and of which it kept no record ${ }^{67}$ There seems to have been no legal obligation to register a marriage and no standard religious ceremony in a state-run temple. ${ }^{68}$ There may have been a feast to mark the occasion of "marriage" 69 and once a couple started living together, they were regarded as being married..$^{70}$ The ancient Egyptians were monogamous (except for the king) and many official records indicate that couples expressed true affection for each other.

The spouses maintained control of the property they brought into the family, while property they acquired during marriage was held jointly. ${ }^{71}$ An Egyptian woman had the right to be provided for during marriage by receiving her subsistence from her husband, without which a marriage ceased to exist, ${ }^{72}$ and it was customary that some households could be enlarged since widowed, divorced, or unmarried women lived with their closest male relative. ${ }^{73}$

The spouses could each own their own property and they could each inherit from their own family, but not from each other. ${ }^{74}$ As a rule husbands and wives did not inherit from each other. This means that the spouse could only inherit when there

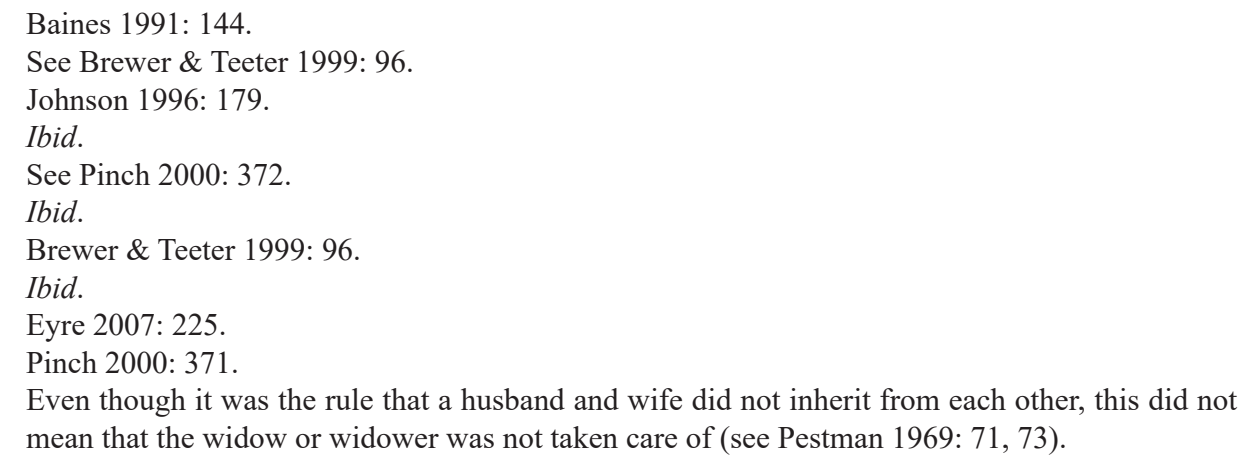


was a "testamentary disposition document" available. Lippert indicates that spouses were not considered heirs in the legal order of succession (her terminology). ${ }^{75}$ In other words, spouses were not considered customary intestate succession heirs of each other.

However, it is important to remember that the wife could be "adopted" by the husband and that she would then become an intestate heir as a "child". In the case of Papyrus Ashmolean Museum 1945.96, Nanefer (the wife) confirms that her husband adopted her. She states inter alia that "(my husband) made me a child of his ... having no son or daughter apart from myself". ${ }^{76}$ For the ancient Egyptians the interest in adoption was based on the results of the devolution of property.

Spouses could still inherit from their own families, financial arrangements might have been made on his or her behalf at the time of marriage, an alimentation obligation could rest on the children or there could be joint property which the couple acquired jointly during the marriage. ${ }^{77}$ Matrimonial property, that is, property acquired during the marriage, was generally divided into three parts. One part would go to the wife if she was widowed (or divorced), and the other two-thirds were held in trust for the children. ${ }^{78}$ However, if there were no children this share would go to the husband's parents or his siblings. ${ }^{79}$ In other words, the joint property was divided into two parts when one of the spouses died, with two-thirds going to the husband or his heirs, and one-third to the wife or her heirs. It would appear that at a woman's death, her children inherited her dowry and therefore upon the death of her husband, an Egyptian woman retained a life estate in her dowry. ${ }^{80}$

An aspect unique to the ancient world, according to Wilkinson, ${ }^{81}$ was the fact that women in ancient Egypt enjoyed a legal status equal to that of men. Women maintained control over their property and after marriage one-third of the new commonly acquired property belonged to the wife. In addition, women were free to dispose of their property as they wished or saw fit. ${ }^{82}$ Papyrus Ashmolean Museum 1945.97 ("Will" of Naunakht) and Papyrus Ashmolean Museum 1945.96 (Adoption Papyrus) are examples where a woman had property and disposed of it by means of a testamentary disposition.

According to Lippert one of the earliest examples of this "one-third" principle is from the Seventeenth Dynasty (stela Cairo JE 52456) and we have several examples from the New Kingdom (Papyrus Turin 2021; Papyrus Geneva D 409; and Papyrus

2013: 3 .

See Gardiner 1941: 23-24.

Pestman 1969: 73

Pinch 2000: 372.

Ibid.

See Versteeg 2002: 138

Wilkinson 2016: 133.

Ibid. 
Ashmolean Museum 1945.97. This "one-third" principle is commonly mentioned in Late Period and Ptolemaic marriage documents, for example Papyrus BM 10120. ${ }^{83}$

However, this "one-third" was not an inheritance at all, since the wife was already endowed with it during her husband's lifetime. This follows from the fact that the wife was also entitled to this "one-third" in the case of divorce (Papyrus Turin 2021 and Papyrus Geneva D 409). ${ }^{84}$

Reference to this "one-third" principle far predates the earliest marriage documents and in these later marriage documents the "one-third" principle is given as a well-known fact. It may therefore be assumed that it was not dependent upon individual arrangements but legally binding from at least the New Kingdom onward. ${ }^{85}$

The wife's right of disposal in respect of this property was usually restricted so that it would fall automatically to her children after her death. ${ }^{86}$ In other words, the rules of customary intestate succession would apply.

\section{The eldest son as sole heir}

According to Lippert it was emphasised in ancient Egypt that the firstborn son of a marriage would be regarded as eldest son in terms of the legal order of succession (which I prefer to call the "customary intestate succession") and in this process would become the main or even the sole heir. ${ }^{87}$ In the Codex Hermopolis we read the following in column VIII 29-VIII 30: "The man to whom daughters are at first born and later on sons are born to him, it is the male children who furnish (literally 'make for') him with an eldest son." 88

The Codex Hermopolis defines the functions of the eldest son, but there is no doubt that these provisions may be projected back to earlier periods. The relevant passages confirm the eldest son as the natural or sole heir in terms of customary intestate succession, unless the de cuius made arrangements prior to his death ${ }^{89} \mathrm{In}$ this regard columns VIII 30-31 state the following: "If a man dies, he having lands, gardens, temple-shares [?] and slaves, he having sons, and he having not assigned [literally 'written'] shares to his children while alive, it is his eldest son who takes possession of his property [or better estate]." ${ }^{90}$ Of importance is that customary intestate succession is confirmed here and specifically the role of the eldest son, who takes possession. It also affirms the role of the testamentary disposition in the sense that it is specifically mentioned that customary intestate succession will only apply if

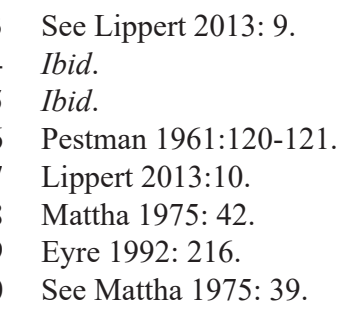


no testamentary disposition was drawn up before death. Noteworthy is also the fact that we have a clear indication here that "property" could include both movable and immovable property.

The purpose of customary intestate succession, as Lippert argues, appears to have been the creation of a sole (male) heir. It is assumed that this person had a certain moral, although probably not a legal, obligation to care for his non-inheriting relatives. ${ }^{91}$

This principle, however, was already weakened in the early New Kingdom since the heir was no longer a sole heir with moral obligations to support his siblings, but acted as a $r w d w$, a caretaker administering the estate for the equal distribution of profits, ${ }^{92}$ as may be derived from the Codex Hermopolis, column VIII 31-33, in the following statement:

If the younger brothers bring action against their elder brother saying 'Let him give us shares of the estate [lit. property] of our father', the elder brother is to write the list of names and write the number of his younger brothers, the children of his father, those alive and those who died before their father died, the eldest son likewise. And he is given the share he prefers. ${ }^{93}$

It is submitted that the eldest son is acting here as caretaker. We are, however, also able to ascertain that the eldest son had first choice to choose a portion, and it is furthermore implied here that the predeceased children are to be represented by their children, confirming that the per stirpes principle applied in ancient Egypt.

However, the caretaker or administrator $(r w \underline{d} w)$ did not always meet his obligations towards his siblings, and in cases like these, the courts of the later New Kingdom went further to strengthen the position of the siblings. ${ }^{94}$

This viewpoint might be behind the development described in the Inscription of Mes from the Nineteenth Dynasty. ${ }^{95}$ In this matter disputed land had originally (in the Eighteenth Dynasty) been passed undivided to heir after heir who acted as $r w \underline{d} w$ caretakers for their non-inheriting siblings. However, when arguments arose regarding the distribution of income, a later court decided to split the land into smaller portions for each descendant. This allowed the parties belonging to the same parentela more direct access to a share of the inheritance and the decision was later contested by the descendants of the original caretakers who wanted to be reinstated into their more advantageous position.

Papyrus Berlin P 3047 is an example of a similar case where one member of the parentela sues his brother who was appointed caretaker because he had not been allowed to profit from his share of the inheritance. In court the $r w d w$ admits

91 2013: 2 .

92 Ibid.

93 See Mattha 1975: 39.

94 See Lippert 2013: 2

95 Ibid. 
the brother's right and declares his consent to splitting the plaintiff's share of the inheritance, which is then let to a temple in order to ensure an income. ${ }^{96}$

According to Lippert the struggle between the older principle of sole heir and the later one of distribution between the descendants had not been fully resolved even in the Twentieth Dynasty. ${ }^{97}$ This may be seen from Papyrus Cairo CG 58092 (recto) where the writer recounts how he refuted the demands of his siblings for their shares of their parents' inheritance. It is important to note that his argument is not that he is the eldest son, but that he alone was burdened financially with the burial of his parents.

\section{Children}

When someone died, the practice in ancient Egypt was that the deceased's children inherited.$^{98}$ Property first passed to a deceased's children. ${ }^{99}$ Children could furthermore inherit from both parents since men as well as women could own property. ${ }^{100}$ It is also important to note that children acquired rights at birth over their parents' matrimonial property and the parents' ability to dispose of such property was limited. ${ }^{101}$

As Pestman suggests, when someone died in ancient Egypt, his or her children were the first to be considered as heirs to the property of the estate. ${ }^{102}$ From the passages of the Codex Hermopolis it appears that by the Late Period the rights of the other siblings as co-heirs were finally fully acknowledged. ${ }^{103}$ The eldest son still took possession of the property (inheritance) and was even allowed to sell part of it, but he was obliged to divide it (or the price, if sold) when his younger siblings demanded it. However, the eldest son retained the most advantageous position since he was entitled to a better or larger share. ${ }^{104}$

The eldest son was also the only heir who was allowed to prove his claims to objects simply by referring, without documentation, to the fact that he inherited them from his father. ${ }^{105}$ Column IX 32-IX 33 of the Codex Hermopolis states as follows: "No man can say 'The property is mine, it is my father's', except the eldest son. He is entitled to say that ' $[t]$ he property is mine, it belongs to my father'."'106

Property given before death as a gift (by a parent) to one of the other children was not regarded as part of the estate upon the parent's death, and if there was no

96 Ibid.

97 See Lippert 2013: 2.

98 Pestman 1969: 59.

99 Versteeg 2002: 137.

100 See Pestman 1969: 59; Johnson 1969: 183.

101 Eyre 2007: 242.

102 1969: 59.

103 See Lippert 2013: 2

104 Lippert 2013: 2; see, also, the discussion in the previous paragraph.

105 Idem at 3.

106 See Mattha 1975: 42. 
donation document, an oath had to be taken by the one who claimed the property. ${ }^{107}$ In this regard column IX 17-IX 19 of the Codex Hermopolis reads as follows:

If a man dies and he has property in the hand [?] of the younger son, and if the elder son brings action against him because of it [the property], and if the younger brother says 'The property [for which he brings action against me is mine, my father is he who gave it to me] (?)', he is made to swear saying, 'It is my father who gave me this property saying "Take it to thyself"". ${ }^{108}$

Children normally inherited from both their father and mother individually and obviously the father and mother themselves inherited from his or her own family. ${ }^{109}$ Since both the father and mother were allowed to own property, the basic principle implies two inheritances. ${ }^{110}$ This shows that the idea of inheritance in the direct line was deeply rooted in the mind-set of the ancient Egyptians.

The above-mentioned principle of "two inheritances" has implications in a situation where one of the parents remarries and has children born out of the second marriage which would mean that the children of both marriages would be entitled to inherit from the relevant parent. ${ }^{111}$ It is submitted that children from the same parentela were therefore entitled to an equal share from the relevant parent's estate.

In cases where a son predeceased the de cuius but left descendants, these grandchildren would take their father's share per stirpes. ${ }^{112}$ It was therefore possible for the descendants to "represent" a predeceased antecedent and this implies that the principle of stirps was known to ancient Egyptians. Westbrook makes the important observation that daughters in ancient Egypt had the same right and the principle of inheriting per stirpes therefore applied to both sons and daughters.

In ancient Egypt children of the deceased preceded siblings of the deceased as legal heirs. The first parentela would be the initial customary intestate heirs. As indicated above, the inheritance first went "down" to the descendants, which included children or their children, effectively applying the principle of per stirps succession. It was only when there were no descendants that siblings were considered. According to Lippert it is possible to observe this system already in the Old Kingdom from the order in which descendants were listed in enumerations of possible heirs, with the Inscription of Kaemnofret being an example. ${ }^{113}$ The Inscription of Kaemnofret consistently names children before brothers and sisters.

107 Lippert 2013: 3.

108 Mattha 1975: 40-41.

109 Allam 2001: 159.

110 Pestman 1969: 59.

111 Idem at 59-60.

112 See Westbrook 2003b: 57.

113 2013: 3. 
According to Versteeg there seems to have been some degree of preference in respect of the inheritance of the eldest son. ${ }^{114}$ Lippert agrees on this matter, confirming that the norm was for the eldest son (first-born son) to inherit the property of his deceased father (and in my view, by implication, also the deceased mother), while at the same time carrying out the duty to bury him (by implication, both the parents) and to take care of the other family members. ${ }^{115}$ Pestman is of the opinion that the eldest son does not only have more obligations, but also more rights than the other heirs. ${ }^{116}$ It was furthermore the eldest son who was obliged to arrange funeral arrangements for his parents and it would appear that he therefore inherited a larger share as a kind of compensation for these duties. ${ }^{117}$

The custom was to keep immovable property intact, and Versteeg maintains that it is for this reason that the children usually inherited immovable property jointly, with the eldest son (or in some cases another sibling acting as the substitute eldest son) managing the jointly owned immovable property for the benefit of the group as a whole. ${ }^{118}$

The principle of per stirpes is supported by Lippert's observation that the eldest son received the inheritance of those siblings who died childless, as is confirmed in the Codex Hermopolis, column IX 5-IX 9. ${ }^{119}$ On this point the Codex states the following in column IX 5-IX 9 (trl in Mattha 1975: 39-40):

If the younger brother brings action saying 'The children whom our eldest brother said "They existed [i.e. belonged] to our father", did not exist as sons [to him]' [?]. He who existed. [If] [?] the younger brother says, 'They did not Exist to our father', the eldest brother is made to swear concerning them saying 'The children whom I said they existed [to our father, they existed as sons to him] (?) [.... There is no] falsehood therein'. He is made to declare 'They were not at all (lit. once) with their mother'. Form of the oath which he is made to take: 'So-and-So [Son of So-and-So] said [...] existed as sons to my father; they died before their father died.' The one concerning whom he does not swear is not allotted a share. [The one concerning whom he swears] is allotted a share.

However, this applied only where a son was acting as eldest son and not where a daughter was doing so. In the case where a daughter was acting as eldest son and there was a childless sibling, the whole inheritance was divided by the number of surviving siblings plus one and she would receive a double share. ${ }^{120} \mathrm{In}$ this regard we read the following in column IX 14-17 from the Codex Hermopolis:

$[\ldots]$ man dies and he has no son but he has a daughter [...] she (?) is given one (?) share in addition to her share (?). If it be (?) daughters whom he has (?), [they give] (?) an extra share

114 2002: 138

115 2013: 1.

116 1969: 58, 66.

117 See Versteeg 2002: 138-139.

118 Idem at 140.

119 2013: 2.

120 Idem at 3. 
to his eldest daughter in addition to her share (?); [it is given in addition (?)] to (?) her (?) one (?) share (?). the eldest daughter is not allowed to say 'Since other children (?) of his are minors (?), let me be given their share (?).' She is not given [their share] (?) [see Mattha 1975: 40].

It would appear that there was a rule of "male before female" among the deceased's children regarding their inheritance. It is possible that this rule also applied to the other categories of siblings and parents of the deceased, but there is no evidence to support this. In ancient Egypt, furthermore, among children of the same gender the older children preceded the younger. ${ }^{121}$ This preference of "older over younger" appears also to have applied to siblings, and if someone died childless, for instance, the deceased's share of the paternal property fell to the deceased's eldest brother, but the same was not applicable to an all-female group. ${ }^{122}$

Regarding gender equality, it would appear that in the legal order of succession there was a clear preference for male children. This prevailed despite the fact that Egyptian women could hold property independently from their husbands and were able to pass it on to whomsoever they liked. ${ }^{123}$ Male children, however, preceded female children as legal heirs and birth-order played an important role. In this regard, column IX 2-3 of the Codex Hermopolis is applicable: "property is next divided into shares according to the number of his children. Then his sons receive shares according to their order (or rank) (of birth) and his daughters receive after them according to their rank of birth". ${ }^{124}$ Older children also preceded younger children among children of the same gender in customary intestate succession. ${ }^{125}$ For the ancient Egyptians the ideal heir was the eldest son.

Allam states that mention is often made of the specific Egyptian legal device called katochè, which gave children a type of preferential claim regarding the devolution of their father's estate in Hellenistic and Roman writings. ${ }^{126}$ The children enjoyed a claim to their father's property during his lifetime and the father could not dispose of it as he pleased without their consent, and after the father's death, the children's claim became a property title.

Pestman makes an important observation that although the children only received their inheritance when the de cuius died, this did not change the fact that the children already had certain rights to this inheritance. ${ }^{127}$ The mere fact that they were children of the parents gave them certain rights to the parents' property of the parents. ${ }^{128}$ In conclusion, it appears that the inheritance was to go first to the descendants per stirpes although prima facie the eldest son had some priority.

121 Idem at 4.

122 See Lippert 2013: 4.

123 Idem at 3.

124 Mattha 1975: 39.

125 Lippert 2013: 3.

126 Allam 2001: 159.

127 1969: 60.

128 Pestman 1969: 62. 


\section{Brothers and sisters}

If a deceased did not have surviving children, the Codex Hermopolis informs us that under these circumstances the estate would revert to the deceased's brothers and sisters. ${ }^{129}$ This would by implication mean that such a person also did not have any surviving grandchildren, or rather any descendants at all, because of the per stirpes principle applicable in ancient Egypt.

According to Pestman the principle that the brothers and sisters would inherit if there were no descendants of the de cuius is found in texts right from the beginning of the second millennium. ${ }^{130}$ From the Stèle Juridique we have the example of Kebsi, who wished to leave his official position to someone, having inherited it from his father, and who said that "[It came] to my father as a property of his brother ... who died without children". ${ }^{131}$

\section{Parents}

If the de cuius had no children, nor any brothers or sisters, his parents would inherit his estate. ${ }^{132}$ Lippert, however, maintains that such a scenario is not attested to and was probably quite rare. ${ }^{133}$

Pestman, furthermore, affirms that there is not a single case known to us where it indeed happened that the parents inherited in circumstances where there were no children nor brothers and sisters. ${ }^{134}$ We do, however, find signs in some texts which support the idea.

An example from a seventh-century deed is the Papyrus Turin 2118 where a brother and sister sell a piece of land, and with the authority of the heirs in mind, they include the following clause: "We have no son, daughter, brother, sister, father, mother or anyone else in the world who could 'go to law' about it." 135 The fact that the father and mother are mentioned in the clause implies that they could also be heirs in terms of customary intestate succession.

\section{Other family members}

Not a single reference is found in available texts to indicate that other family members might have been eligible to inherit from the de cuius. It is submitted that the clause from Papyrus Turin 2118 might also be seen as a reference to other members of the

129 Pestman 1969: 68.

130 Ibid.

131 Ibid.

132 See Pestman 1969: 70.

133 2013: 3.

134 1969: 70.

135 Ibid. 
family, or rather the extended family beyond the parents, because reference is made to "anyone else". It is mentioned at the end after the mentioning of descendants and antecedents and might refer to siblings within the extended family; in other words, the nearest blood relative beyond the parents. This is a principle familiar to modernday law of intestate succession.

\section{Conclusion}

There was a link between belief in the afterlife and the first signs of succession law. The socio-economic circumstances of the ancient Egyptians played an important role in the development of succession law. In the case of customary intestate succession law, the property (or rather the estate) went to the descendants first. For the ancient Egyptians the ideal was for the eldest son to be the sole heir for the purpose of sustenance of the de cuius, taking care of the nuclear family and protecting family property by keeping it intact. This position of the eldest son as sole heir eventually weakened as he acted as caretaker for his siblings (who effectively also became intestate heirs). The children were the intestate heirs, and male and older children preceded. Adoption was known in ancient Egypt and an "adopted child" could inherit in terms of customary intestate succession. The principle of per stirpes was applied and the descendants of the first parentela had priority over the second and further parentela. In the absence of descendants, the estate went to the deceased's brothers and sisters. In their absence the estate went to the parents and in their absence to the deceased's collaterals. Husbands and wives did not inherit from each other in terms of customary intestate succession. The ancient Egyptians' reliance on custom, tradition and precedent indicates that we can form a very good idea of their views on customary intestate succession which is important when we study the broader subject of succession law in ancient Egypt. This emphasis on custom, tradition and precedent would appear to be important first signs of jurisprudence in ancient Egyptian succession law, especially customary intestate succession.

\section{Bibliography}

Allam, S (2001) "Inheritance" in Redford Oxford Encyclopedia of Ancient Egypt vol 2 Oxford University Press: 158-161

Allam, S (2007a) "Foundations in Pharaonic Egypt: The oldest known private endowments in history" in Die Welt des Orients 37: 8-30

Allam, S (2007b) "Law" in Wilkinson T (ed) The Egyptian World (London): 263-274

Baines, J (1991) "Society, morality and religious practice" in Shafer BE (ed) Religion in Ancient Egypt (Ithaca, NY): 123-200

Bedell, ED (1985) Criminal Law in the Egyptian Ramesside Period (unpublished PhD dissertation, University of Michigan)

Brewer, DJ \& E Teeter (1999) Egypt and the Egyptians (Cambridge) 


\section{THE BASIC TENETS OF INTESTATE (CUSTOMARY) SUCCESSION LAW}

Burdick, WL (1989) The Principles of Roman Law and Their Relation to Modern Law (Florida)

Corbett, MM, G Hofmeyer \& E Kahn (2001) The Law of Succession in South Africa (Lansdowne)

David, R (2002) Religion and Magic in Ancient Egypt (London)

Eyre, CJ (1992) “The Adoption Papyrus in social context” in J of Egyption Archaeology 78: 207-221

Fleming JG (1978) "Changing functions of succession laws" in American J of Comparative Law 26(2): $233-238$

Gardiner, AH (1941) “Adoption extraordinary” in J of Egyption Archaeology 26: 23-29

Goedicke, H (1970) Die privaten Rechtsinschriften aus dem Alten Reich (Wien)

Helck, W (1963) "Der Papyrus Berlin" P 3047 J of the American Research Center in Egypt 2: $65-73$

Ikram, S (2007) “Afterlife beliefs and burial customs" in Wilkinson (2007b): 340-354

Jasnow, R (2003) "Egypt: Old Kingdom and First Intermediate Period" in Westbrook (2003a): 93-140

Johnson, JH (1996) "The legal status of women in ancient Egypt" in Capel \& Markoe 1996: $175-185$

Lippert, S (2013) "Inheritance" in Frood, E \& W Wendrich (eds) UCLA Encyclopaedia of Egyptology (Los Angeles: UCLA Department of Near Eastern Languages and Culture): 1-20 available at http://digital2.library.ucla.edu/viewItem.do? ark $=21198 / \mathrm{zz} 002 \mathrm{hg} 0 \mathrm{wl}$ (accessed 23 May 2017)

Mattha, G (1975) The Demotic Legal Code of Hermopolis West (Cairo: Institut français d'archéologie orientale du Caire)

Muhs, B (2016) The Ancient Egyptian Economy: $3000-30$ BCE (Cambridge)

Pestman, PW (1969) "The law of succession in ancient Egypt" in Brugman, J (ed) Essays on Oriental Laws of Succession (Leiden): 58-77

Pinch, G (2000) "Private life in ancient Egypt" in Sasson, JM Civilizations of the Ancient Near East 3: 363-382

Rowlandson, J \& R Takahashi (2009) "Brother-sister marriage and inheritance strategies in GrecoRoman Egypt" J of Roman Studies 99: 104-139

Sasson, JM (ed) (2000) Civilizations of the Ancient Near East (Peabody)

Schoeman, MC \& MJ De Waal (2005) Law of Succession (Cape Town)

Seidl, E (1957) Einführung in die Ägyptische Rechtsgeschichte bis zum Ende des Neuen Reiches (Glückstadt)

Strudwick, NG (2005) Texts from the Pyramid Age (Atlanta: Society for Biblical Literature)

Sweeney, D (2002) "Gender and conversational tactics in 'The Contendings of Horus and Seth"' $J$ of Egyptian Archaeology 88: 141-162

Taylor, JH (2001) Death and the Afterlife in Ancient Egypt (London: British Museum)

Theodorides, A (1971) "The concept of law in ancient Egypt" in Harris, JR (ed) The Legacy of Egypt (Oxford): 291-322

Van Blerk, NJ (2018) Aspects of Succession Law in Ancient Egypt with Specific Reference to Testamentary Dispositions (unpublished PhD thesis, University of South Africa)

Van der Merwe, NJ \& CJ Rowland (1997) Die Suid-Afrikaanse Erfreg (Pretoria)

Versteeg, R (2002) Law in Ancient Egypt (Durham) 
Westbrook, R (ed) (2003a) A History of Ancient Near Eastern Law vol 1 (Leiden)

Westbrook, R (2003b) "Introduction: The character of ancient Near Eastern law" in Westbrook (2003a: 1-92)

Wilkinson, T (2007) The Egyptian World (London)

Wilkinson, T (2016) Writings from Ancient Egypt (London)

\section{Addendum A}

\section{Timeline}

(Source: Wilkinson 2016: xxxi-xxxiii)

\begin{tabular}{|l|l|}
\hline PERIOD / DATES (BCE) / DYNASTY / KING & DEVELOPMENTS IN EGYPT \\
\hline Early Dynastic Period, 2950-2575 & \\
\hline First Dynasty, 2950-2750 & \\
\hline Second Dynasty, 2750-2650 & Step Pyramids at Saqqara \\
\hline Third Dynasty, 2650-2575 & Great Pyramid at Giza \\
\hline Old Kingdom, 2575-2125 & Pyramid Texts \\
\hline Fourth Dynasty, 2575-2450 & Harkhuf's expeditions \\
\hline $\begin{array}{l}\text { Fifth Dynasty, 2450-2325 } \\
\text { (nine kings, ending with Unas, 2350-2325) }\end{array}$ & \\
\hline $\begin{array}{l}\text { Sixth Dynasty, 2325-2175 } \\
\text { (five kings, ending with Pepi II, 2260-2175 }\end{array}$ & Civil war \\
\hline Eighth Dynasty, 2175-2125 & \\
\hline First Intermediate Period, 2125-2010 & \\
\hline Ninth/Tenth Dynasty, 2125-1975 & Golden age of literature \\
\hline $\begin{array}{l}\text { Eleventh Dynasty (1st part), 2080-2010 } \\
\text { (three kings, including Intef II, 2070-2020) } \\
\text { Senusret I, 1918-1875 } \\
\text { Senusret III, 1836-1818) }\end{array}$ & \\
\hline Middle Kingdom, 2010-1630 & \\
\hline $\begin{array}{l}\text { Eleventh Dynasty (2nd part), 2010-1938 } \\
\text { (three kings, ending with Mentuhotep IV, 1948-1938) }\end{array}$ & \\
\hline $\begin{array}{l}\text { Thirteenth Dynasty, 1755-1630 Dynasty, 1938-1755 } \\
\text { (eings, including: }\end{array}$ & \\
\hline
\end{tabular}


THE BASIC TENETS OF INTESTATE (CUSTOMARY) SUCCESSION LAW

\begin{tabular}{|c|c|}
\hline PERIOD / DATES (BCE) / DYNASTY / KING & DEVELOPMENTS IN EGYPT \\
\hline Second Intermediate Period, 1630-1539 & Civil war \\
\hline \multicolumn{2}{|l|}{ Fourteenth Dynasty, c 1630} \\
\hline Fifteenth Dynasty 1630-1520 & Hyksos invasion \\
\hline \multicolumn{2}{|l|}{ Sixteenth Dynasty, 1630-1565 } \\
\hline \multicolumn{2}{|l|}{$\begin{array}{l}\text { Seventeenth Dynasty, 1570-1539 } \\
\text { (several kings, ending with Kamose, 1541-1539) }\end{array}$} \\
\hline \multicolumn{2}{|l|}{ New Kingdom, 1539-1069 } \\
\hline $\begin{array}{l}\text { Eighteenth Dynasty, 1539-1292 } \\
\text { (fifteen kings, including: } \\
\text { Ahmose, 1539-1514 } \\
\text { Thutmose I, 1493-1481 } \\
\text { Thutmose III, 1479-1425 } \\
\text { Hatshepsut, 1473-1458 } \\
\text { Amenhotep III, 1390-1353 } \\
\text { Akhenaten, 1353-1336 } \\
\text { Tutankhamun, 1332-1322 } \\
\text { Horemheb, 1319-1292) }\end{array}$ & $\begin{array}{l}\text { Reunification } \\
\text { Battle of Megiddo } \\
\text { Amarna revolution }\end{array}$ \\
\hline \multicolumn{2}{|l|}{ Ramesside Period, 1292-1069 } \\
\hline \multicolumn{2}{|l|}{ Nineteenth Dynasty, 1292-1190 } \\
\hline \multicolumn{2}{|l|}{$\begin{array}{l}\text { Twentieth Dynasty, 1190-1069 } \\
\text { Ten kings, including } \\
\text { Ramesses V, 1150-1145 } \\
\text { Ramesses XI, 1099-1069 }\end{array}$} \\
\hline \multicolumn{2}{|l|}{ Third Intermediate Period, 1069-664 } \\
\hline $\begin{array}{l}\text { Twenty-first Dynasty, 1069-945 } \\
\text { Twenty-second Dynasty, 945-715 } \\
\text { Twenty-third Dynasty, 838-720 } \\
\text { Twenty-fourth Dynasty, 740-715 } \\
\text { Twenty-fifth Dynasty, 728-657 } \\
\text { (five kings, starting with Piankhi, 747-716) }\end{array}$ & $\begin{array}{l}\text { Political division } \\
\text { Kushite conquest }\end{array}$ \\
\hline PERIOD / DATES (BCE) / DYNASTY / KING & DEVELOPMENTS IN EGYPT \\
\hline \multicolumn{2}{|l|}{ Late Period, 664-332 } \\
\hline \multicolumn{2}{|l|}{$\begin{array}{l}\text { Twenty-sixth Dynasty, 664-525 } \\
\text { (six kings, starting with Psamtek I, 664-610) }\end{array}$} \\
\hline $\begin{array}{l}\text { Twenty-seventh Dynasty } \\
\text { (First Persian Period), 525-404 } \\
\text { (five kings, including Darius I, 522-486) }\end{array}$ & Persian conquest \\
\hline Twenty-eighth Dynasty, 404-399 & \\
\hline
\end{tabular}


NJ VAN BLERK

\begin{tabular}{|l|l|}
\hline Twenty-ninth Dynasty, 399-380 & \\
\hline Thirtieth Dynasty, 380-343 & \\
\hline $\begin{array}{l}\text { Thirty-first Dynasty } \\
\text { (Second Persian Period), 343-332 }\end{array}$ & \\
\hline Macedonian Dynasty, 332-309 & \\
\hline Alexander the Great, 332-323 & \\
\hline Ptolemaic Period, 309-30 & Death of Cleopatra \\
\hline
\end{tabular}

